\title{
Energy Price Reform in
}

Saudi Arabia: Modeling the

\section{Economic and Environmental}

Impact and Understanding

the Demand Response

Mohammad Al Dubyan, Anwar Gasim 


\section{About KAPSARC}

The King Abdullah Petroleum Studies and Research Center (KAPSARC) is a non-profit global institution dedicated to independent research into energy economics, policy, technology and the environment across all types of energy. KAPSARC's mandate is to advance the understanding of energy challenges and opportunities facing the world today and tomorrow, through unbiased, independent, and high-caliber research for the benefit of society. KAPSARC is located in Riyadh, Saudi Arabia.

This publication is also available in Arabic.

\section{Legal Notice}

(C) Copyright 2020 King Abdullah Petroleum Studies and Research Center ("KAPSARC"). This Document (and any information, data or materials contained therein) (the "Document") shall not be used without the proper attribution to KAPSARC. The Document shall not be reproduced, in whole or in part, without the written permission of KAPSARC. KAPSARC makes no warranty, representation or undertaking whether expressed or implied, nor does it assume any legal liability, whether direct or indirect, or responsibility for the accuracy, completeness, or usefulness of any information that is contained in the Document. Nothing in the Document constitutes or shall be implied to constitute advice, recommendation or option. The views and opinions expressed in this publication are those of the authors and do not necessarily reflect the official views or position of KAPSARC. 


\section{Key Points}

his study examines the economic impacts of energy price reform in Saudi Arabia. Its key findings include the following:

In 2018, gasoline price reform delivered a total welfare gain of 8.8 billion Saudi riyals (SAR), comprising a market surplus of SAR 2.1 billion and additional economic benefits worth SAR 6.6 billion. The latter reflects reduced carbon dioxide (CO2) emissions, air pollution, congestion and road accidents.

Residential electricity price reform brought a total welfare gain of SAR 3.8 billion in the same year, primarily from a SAR 3.4 billion market surplus. Decreased CO2 emissions and air pollution from power plants account for the remaining SAR 0.4 billion.

Government revenue rose by SAR 32.8 billion in 2018 due to combined gasoline and electricity price reforms.

In 2018, residential electricity usage fell by 13.0 terawatthours (TWh) and gasoline consumption by 2.2 billion liters versus 2017. Higher residential electricity and gasoline prices contributed 9.1 TWh and 1.9 billion liters, respectively, to these decreases.

Between 2014 and 2018, energy efficiency improvements to residential buildings cut electricity consumption by at least 7.7 TWh. This played a major role in the slower growth of residential electricity consumption over the last few years. 


\section{Summary}

$\mathrm{T}$ he government of Saudi Arabia, like many around the world, has long set domestic energy prices far below international market levels. This helps keep prices stable and energy affordable, providing important support to lower-income households. However, subsidized energy can encourage higher demand growth and wasteful consumption, and limit the incentive to invest in energy efficiency. In addition, as a leading energy exporter, the Kingdom foregoes substantial government revenue by selling energy domestically at much lower prices than could be earned on the global market.

With the launch in 2016 of Saudi Vision 2030 (SV2030), the government's blueprint for national development, Saudi Arabia has entered a period of accelerated economic and social change. SV2030 encompasses 13 realization programs targeting 96 strategic objectives, with the energy sector representing one of the most visible and important areas of reform. The government has committed to reducing energy subsidies to align domestic prices more closely with the international market, and it has already implemented initial regulatory changes. One of the many aims of SV2030 is to improve the competitiveness of the energy sector, and it was noted that "providing subsidies with no clear eligibility criteria is a substantial obstacle to the energy sector's competitiveness.

To better understand the impact of energy price reform on the Kingdom's economy, we econometrically model demand for gasoline and residential electricity using a structural time series approach. Our analysis finds price and income inelasticity for both. We estimate long-run price and income elasticities for gasoline of -0.13 and 0.15 , and for residential electricity of -0.09 and 0.22 , respectively.
The results align with previous studies published before the SV2030 reforms, indicating that consumers in Saudi Arabia are not very responsive to price changes. For gasoline, the absence of alternatives to personal vehicles for transportation in major cities likely bears much of the blame. As projects such as the Riyadh Metro become operational, consumers will likely become more responsive to higher gasoline prices, increasing price elasticity in the coming years. It is possible that the need for air conditioning in a country with a hot climate limits the willingness of households to reduce their consumption, particularly during very hot summer months when this is a key issue. However, this is less of an issue in many cities in Saudi Arabia during winter.

We conduct a welfare analysis by using the models to estimate the economic and environmental impacts of cutting subsidies. The calculations reveal total welfare gains in $\mathbf{2 0 1 8}$ of $\mathbf{8 . 8}$ billion Saudi riyals (SAR) for gasoline and SAR 2.8 billion for residential electricity, taking into account both direct and indirect effects. The price reforms directly generated market surpluses of SAR 2.1 billion and SAR 3.4 billion for gasoline and residential electricity, respectively. They also created other economic benefits worth SAR 6.6 billion for gasoline and SAR 0.4 billion for residential electricity by decreasing negative externalities, including carbon emissions and air pollution. The high value for gasoline reflects two additional problems linked to its consumption: traffic congestion and road accidents. Over a longer timeline, such welfare gains will have a significant cumulative impact on the economy.

Gasoline and electricity subsidies greatly affect Saudi Arabia's government revenues, because the state fully or partially owns most energy companies. We estimate that price reforms lifted government 
income in 2018 by SAR 18.4 billion for gasoline and SAR 14.4 billion for residential electricity. Our calculations apply the direct and indirect shares of state ownership of firms such as the Saudi Electricity Company and various refineries.

Finally, we apply decomposition analysis to our econometric models to understand which factors contributed to the changes in energy consumption. We take particular interest in 2018, which saw gasoline and electricity use decline substantially year-on-year. The decomposition analysis highlights two important points related to price reform and energy efficiency.

First, energy price reforms accounted for the majority of the decreases: 1.9 billion of the 2.2 billion liters of gasoline and 9.1 of the 13.0 terawatthours (TWh) of residential electricity. Although our regression analysis shows that gasoline and residential electricity demand is price inelastic, the very large percentage price increases in 2018, following the second fuel price reform, resulted in these considerable declines in energy consumption.

Second, we did not detect improvements from energy efficiency measures for gasoline consumption, although exogenous factors (such as urban sprawl, congestion, and road network expansion) may have obscured any such gains. However, for residential electricity, the decomposition analysis did reveal a significant impact, with consumption falling by at least 7.7 TWh between 2014 and 2018 due to increased energy efficiency. As consumers continue to replace older cars and electrical appliances, we expect to observe greater energy savings in both gasoline and residential electricity due to energy efficiency measures. 
E nergy demand in Saudi Arabia has surged in recent decades. From 1983 to 2018, annual gasoline consumption quadrupled from 8 billion to 32 billion liters (MEIM 2019; Jodi Oil 2019), while residential electricity use jumped from 15 to 130 terawatthours (TWh) (MEIM 2019; SAMA 2019). Along with steady economic and population growth, subsidized energy prices have played an important role in these increases.

The government of Saudi Arabia, like many around the world, has long set domestic energy prices far below international market levels. This helps keep prices stable and energy affordable, providing important support to lower-income households. However, subsidized energy can encourage higher demand growth and wasteful consumption, and limit the incentive to invest in energy efficiency. Although in the Kingdom energy is often sold at or above production costs, the gap between domestic and international prices represents forgone revenue on crude oil and other fuels not exported - an implicit subsidy.

Lahn and Stevens (2011) looked at Saudi Arabia's rapid growth in domestic energy consumption and ran simulations that showed the country could "become a net importer of oil by 2038." This carries implications not only for global energy markets, but also for emissions targets, given that Saudi Arabia is already one of the largest emitters in the Middle East. According to BP (2019), the Kingdom emitted 571 million tonnes of carbon dioxide (CO2) in 2018, almost a quarter of the region's total $\mathrm{CO} 2$ emissions. If these trends continue, they will strain Saudi Arabia's fiscal budget and hinder its climate change mitigation efforts.

However, the government has recently set the Kingdom on a path of substantial economic and social reform under Saudi Vision 2030 (SV2030), its national development masterplan. Launched in
2016, SV2030 encompasses 96 strategic objectives grouped under 13 realization programs, of which the Fiscal Balance Program (FBP) is among the most important. In 2015, following the collapse of international oil prices in late 2014, Saudi Arabia recorded its highest-ever budget deficit. The FBP aims to balance the government budget by 2023 by expanding oil and non-oil revenues and improving spending efficiency (FBP 2017, 2018, 2019).

The scheme includes a value added tax, levies on expatriates, and energy price reform to align domestic prices more closely with the international market.

The government has started raising energy prices (removing subsidies) in stages, an approach that offers significant advantages (Ekins and Barker 2001). Gradual increases avoid sudden shocks to the market and give consumers sufficient time to anticipate higher energy costs, allowing them to adjust their future purchases and other decisions related to energy consumption. Slowly phasing in higher prices also allows businesses and consumers to continue using existing capital goods, such as vehicles or air conditioners, until the end of their planned lifecycles instead of replacing them prematurely. The government launched what is commonly known as the 'first wave' of energy price reform between December 30, 2015 and January 1, 2016, with small increases to fuel, electricity, and water prices. It implemented the 'second wave' at the start of 2018, focusing on gasoline and electricity, the two major sources of energy consumed by households. Table 1 shows the results of both waves of energy price reforms.

Raising energy prices is arguably one of the most cost-effective and efficient policy instruments for managing domestic energy consumption, encouraging greater investment in energy efficiency, influencing consumer behavior, and reducing negative externalities related to fossil fuels (Parry et 
al. 2014). Nevertheless, policymakers often look for alternatives because higher energy prices impose a heavy burden on lower-income households. This regressive impact can create a barrier to higher energy prices, both in developing countries, where eliminating subsidies is often the focus, and in developed countries, where a carbon tax may be the goal.

To minimize the negative impact of increased energy costs on lower- and middle-income households, the government launched the Citizens' Account Program alongside the second wave of reforms. The scheme, which provides eligible families with monthly cash transfers, is funded using revenue generated from the higher energy prices (FBP 2017). Energy price reform and the Citizens' Account Program lift government revenue while providing targeted support to the most affected households. The Citizens' Account Program is key to the success of price reform. The International Monetary Fund recently highlighted the program in its Article IV consultation with Saudi Arabia (IMF 2018). In contrast, the previous policy of lower, administered, energy prices strained the government budget and disproportionately benefited higher-income households since they generally consume more energy.

Table 1. Energy prices (nominal) before and after reforms.

\begin{tabular}{|c|c|c|c|c|c|c|c|c|}
\hline Type & $\begin{array}{l}\text { Prices befor } \\
\text { of price refo }\end{array}$ & $\begin{array}{l}\text { e first wave } \\
\text { rm }\end{array}$ & $\begin{array}{l}\text { Prices after } \\
\text { of price refo } \\
2016)\end{array}$ & $\begin{array}{l}\text { irst wave } \\
\text { Im (Jan 1, }\end{array}$ & $\begin{array}{l}\text { Percentage } \\
\text { change }\end{array}$ & $\begin{array}{l}\text { Prices after } \\
\text { wave of pric } \\
\text { (Jan 1, 2018) }\end{array}$ & $\begin{array}{l}\text { second } \\
\text { e reform }\end{array}$ & $\begin{array}{l}\text { Percentage } \\
\text { change }\end{array}$ \\
\hline Gasoline & SAR / liter & US\$ / liter & SAR / liter & US\$ / liter & & SAR / liter & US\$ / liter & \\
\hline $91 \mathrm{RON}$ & 0.45 & 0.12 & 0.75 & 0.20 & $67 \%$ & 1.37 & 0.37 & $+83 \%$ \\
\hline $95 \mathrm{RON}$ & 0.60 & 0.16 & 0.90 & 0.24 & $50 \%$ & 2.04 & 0.54 & $+127 \%$ \\
\hline $\begin{array}{l}\text { Electricity } \\
\text { (residential)* }\end{array}$ & SAR / kWh & US\$ / kWh & SAR / kWh & US\$ / kWh & & SAR / kWh & US\$ / kWh & \\
\hline $0-2,000 \mathrm{kWh}$ & 0.05 & 0.01 & 0.05 & 0.01 & $0 \%$ & 0.18 & 0.05 & $+260 \%$ \\
\hline $2,001-4,000 \mathrm{kWh}$ & 0.10 & 0.03 & 0.10 & 0.03 & $0 \%$ & 0.18 & 0.05 & $+80 \%$ \\
\hline $4,001-6,000 \mathrm{kWh}$ & 0.12 & 0.03 & 0.20 & 0.05 & $67 \%$ & 0.18 & 0.05 & $-10 \%$ \\
\hline $6,001+\mathrm{kWh}$ & 0.15 to 0.26 & 0.04 to 0.07 & 0.30 & 0.08 & N/A & 0.30 & 0.08 & $0 \%$ \\
\hline
\end{tabular}

Notes: *Electricity consumption is billed according to the level of consumption in each month.

The values are shown in Saudi Arabian Riyals (SAR) and United States dollars (US\$); RON = research octane number. Sources: Saudi Aramco (n.d.); ECRA (2013b); ECRA (2019).

To help inform policymakers, this study models the impact of energy price reforms on energy demand, consumers, producers, the government, the environment, and social welfare in Saudi Arabia. We develop econometric models for gasoline and residential electricity and use them to conduct a welfare analysis, something very few previous studies have done. Atalla, Gasim, and Hunt (2018) formulated a gasoline demand equation and employed it to perform a welfare analysis of the
Kingdom's 2016 gasoline price increase, but their estimation period ended before any of the reforms were implemented. Blazquez, Hunt, and Manzano (2018) utilized a dynamic stochastic general equilibrium model to test hypothetical scenarios in which the country's domestic oil price is gradually increased. To the best of our knowledge, no prior study of this kind has evaluated the impact of the 2018 gasoline and residential electricity price reforms, a gap we aim to fill. 


\section{Econometric methods}

\section{Modeling gasoline demand}

We model aggregate gasoline demand per capita as a function of the real average gasoline price and real income per capita.

$G_{t}=f\left(P G_{t}, Y_{t}, U E D T_{t}{ }^{G}\right)$

Where:

$G_{t}=$ Aggregate gasoline consumption per capita;

$P G_{t}=$ Real weighted average gasoline price;

$Y_{t}=$ Real income per capita (measured using real gross domestic product [GDP] per capita);

$U E D T_{t}^{G}=$ Underlying energy demand trend for gasoline consumption.

The subscript $t$ denotes the year. The superscript $G$ denotes the gasoline sector.

$U E D T_{t}^{G}$ denotes the UEDT for the gasoline sector at time $t$. This UEDT is an unobservable non-linear stochastic trend estimated by the model that captures the effect of exogenous factors not included in the gasoline demand model. These include fuel economy improvements and expansions in the road network. These time-varying factors are left out due to a lack of data.

Equation (1) is estimated using the following dynamic autoregressive distributed lag specification:

$g_{t}=\alpha_{1}{ }^{G} g_{t-1}+\alpha_{2}{ }^{G} g_{t-2}+\beta_{0}{ }^{G} p g_{t}+\beta_{1}{ }^{G} p g_{t-1}+$ $\beta_{2}{ }^{G} p g_{t-2}+\gamma_{0}{ }^{G} y_{t}+\gamma_{1}{ }^{G} y_{t-1}+\gamma_{2}{ }^{G} y_{t-2}+U E D T_{t}{ }^{G}+\varepsilon_{t}{ }^{G}$
The variables $g_{t}, p g_{t}$, and $y_{t}$ are the natural logarithms of $G_{t}, P G_{t}$, and $Y_{t}$ in year $t$, respectively, and $\varepsilon_{t}$ is the random error term. The other Greek letters denote elasticities.

\section{Modeling electricity demand}

We model aggregate residential electricity demand per capita as a function of the real average electricity price, real income per capita, and cooling degree days (CDD).

$E_{t}=f\left(P E_{t}, Y_{t}, C D D_{t}, U E D T_{t}^{R}\right)$

Where:

$E_{t}=$ Aggregate residential electricity consumption per capita;

$P E_{t}=$ Real weighted average residential electricity price;

$Y_{t}=$ Real income per capita (measured using real GDP per capita);

$C D D_{t}=$ Annual cooling degree days (base temperature $=18$ degrees Celsius);

$U E D T_{t}^{E}=$ Underlying energy demand trend for residential electricity consumption.

The subscript $t$ denotes the year. The superscript $E$ denotes the residential electricity sector.

$U E D T_{t}^{E}$ denotes the UEDT for the residential electricity sector at time $t$. This UEDT is an unobservable non-linear stochastic trend estimated by the model that captures the effect of exogenous factors not included in the electricity demand model, such as energy efficiency and appliance ownership. These time-varying factors are left out due to a lack of data. 
Equation (3) is estimated using the following dynamic autoregressive distributed lag specification:

$$
\begin{aligned}
& e_{t}=\alpha_{1}{ }^{E} e_{t-1}+\alpha_{2}{ }^{E} e_{t-2}+\beta_{0}{ }^{E} p e_{t}+\beta_{1}{ }^{E} p e_{t-1}+ \\
& \beta_{2}{ }^{E} p e_{t-2}+\gamma_{0}{ }^{E} y_{t}+\gamma_{1}{ }^{E} y_{t-1}+\gamma_{2}{ }^{E} y_{t-2}+ \\
& \delta_{0}{ }^{E} c d d_{t}+\delta_{1}{ }^{E} c d d_{t-1}+\delta_{2}{ }^{E} c d d_{t-2}+U E D T_{t}{ }^{E}+\varepsilon_{t}{ }^{E}
\end{aligned}
$$

The variables $e_{t}, p e_{t}, y_{t}$, and $c d d_{t}$ are the natural logarithms of $E_{t}, P E_{t}, Y_{t}$, and $C D D_{t}$ in year $t$, respectively, and $\varepsilon_{t}$ is a random white noise error term. The other Greek letters denote the elasticities.

\section{Decomposition methods}

We utilize decomposition analysis to quantify the drivers or determinants of a change in an aggregate economic, environmental, or energy-related indicator (Ang and Zhang 2000). The logarithmic mean divisa index (LMDI) method introduced by Ang, Zhang, and Hoi in 1998 has become the preferred tool for decomposition analysis because it is relatively easy to implement and does not leave behind a decomposition residual, as noted by Ang (2005) and Ang (2015).

This paper applies the additive LMDI method to an econometrically derived energy demand equation to quantify the contributions of the drivers to the change in energy consumption. We follow the approach used by Alarenan, Gasim, and Hunt (2019).

For gasoline, the decomposition analysis divides year-on-year changes in consumption into six drivers or contributors: income, population, gasoline price, UEDT, a lagged effect, and an econometric residual. For residential electricity, the six drivers are income, population, residential electricity price, UEDT, weather, and an econometric residual.

\section{Data}

To formulate the energy demand equations, we use annual time-series data. Both models use identical GDP, population, and consumer price index (CPI) data. The gasoline model adds gasoline consumption and real weighted average gasoline price, while the residential electricity model incorporates residential electricity consumption, real weighted average electricity price for the residential sector, and CDD.

We obtained gasoline consumption statistics from MEIM (2019) and Jodi Oil (2019), and took residential electricity use data from MEIM (2019) and SAMA (2019). Figure 1 shows how gasoline and residential electricity use have evolved from 1983 to 2018, highlighting the rapid growth in energy demand.

Because the government sets energy prices by decree, they change sporadically throughout the study period. Figure 2 shows the weighted average prices (in nominal terms) for gasoline and residential electricity, highlighting the impact of the reforms in 2018. The nominal prices were then deflated using CPI values from the General Authority for Statistics (GaStat) (2019).

We estimated the weighted average gasoline price using price and consumption data from Saudi Aramco (n.d.) for the two available grades. While the Kingdom's gasoline sector previously offered only 95-octane fuel, in 2007 retailers introduced a 91-octane variety that tends to cost around SAR 0.15 less. Similarly, we calculated a weighted average residential electricity price based on price and invoice data from Saudi Aramco (n.d.) and the Electricity \& Cogeneration Regulatory Authority (ECRA) (2008-2017; 2013b; 2019). In Saudi Arabia, the Saudi Electricity Company prices electricity 
according to consumption and bills households on a monthly basis. For example, in 2015, residential electricity users paid $0.05 \mathrm{SAR} / \mathrm{kWh}$ for the first $2,000 \mathrm{kWh}$ of monthly consumption. Households that consumed $4,000 \mathrm{kWh}$ per month paid $0.10 \mathrm{SAR}$ for each kWh in the 2,000-4,000 kWh consumption segment. Invoice data were used to assign weights to the prices at different segments of consumption, which were then averaged. To fill gaps in the invoice data from ECRA (2008-2017), we linearly extrapolated from the available numbers.

Figure 1. Energy consumption in Saudi Arabia.

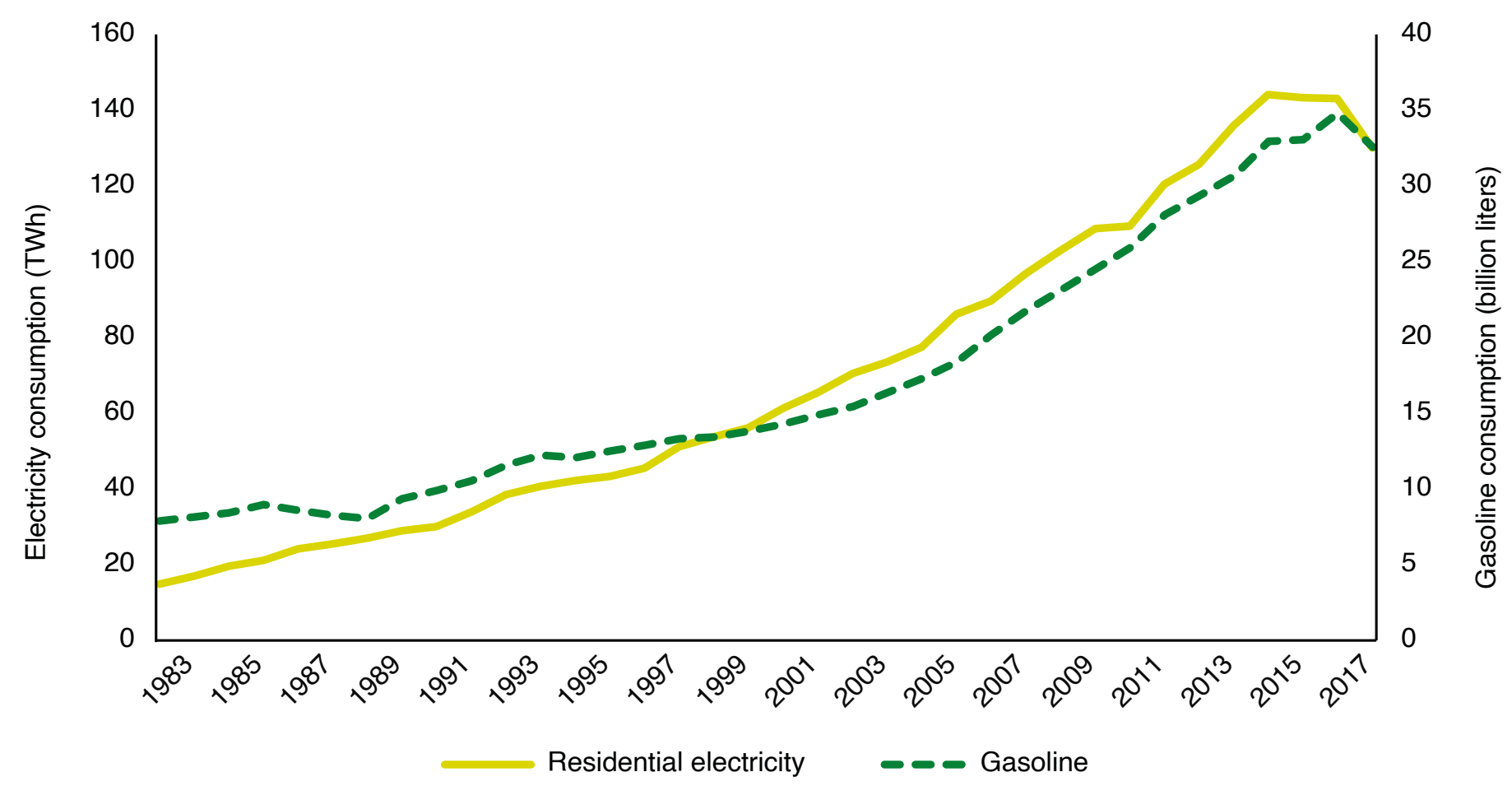

Sources: Jodi Oil (2019); MEIM (2019); SAMA (2019).

Economic development and population growth largely determine gasoline and residential electricity consumption. We obtained real GDP data from GaStat (2019) and population data from the World Bank (2019) and GaStat (2019). Figure 3 reveals how both variables evolved over the study period.

We make a slight adjustment to the 2018 population figures due to recent legislation affecting foreign workers. According to numerous news reports (e.g., Argaam [2019]), the levies on expatriates imposed as part of the FBP, and other 'Saudization' policies, caused as many as 1.6 million aliens to leave between 2017 and 2018. However, the
World Bank and GaStat estimates do not reflect this trend. Therefore, we revised their figures for 2018 using data from GaStat's 2019 Labor Force Survey. Appendix A provides more details on this calculation.

The widespread use of air conditioning in Saudi Arabia generates high demand for electricity. To estimate this we employ CDD, which measures how many degrees the average daily ambient temperature exceeds 18 degrees Celsius, as shown in Figure 4. We constructed this variable using temperature data from the World Bank's Climate Change Knowledge Portal (2018) and AccuWeather (2019). 
Figure 2. Weighted average energy prices in Saudi Arabia.

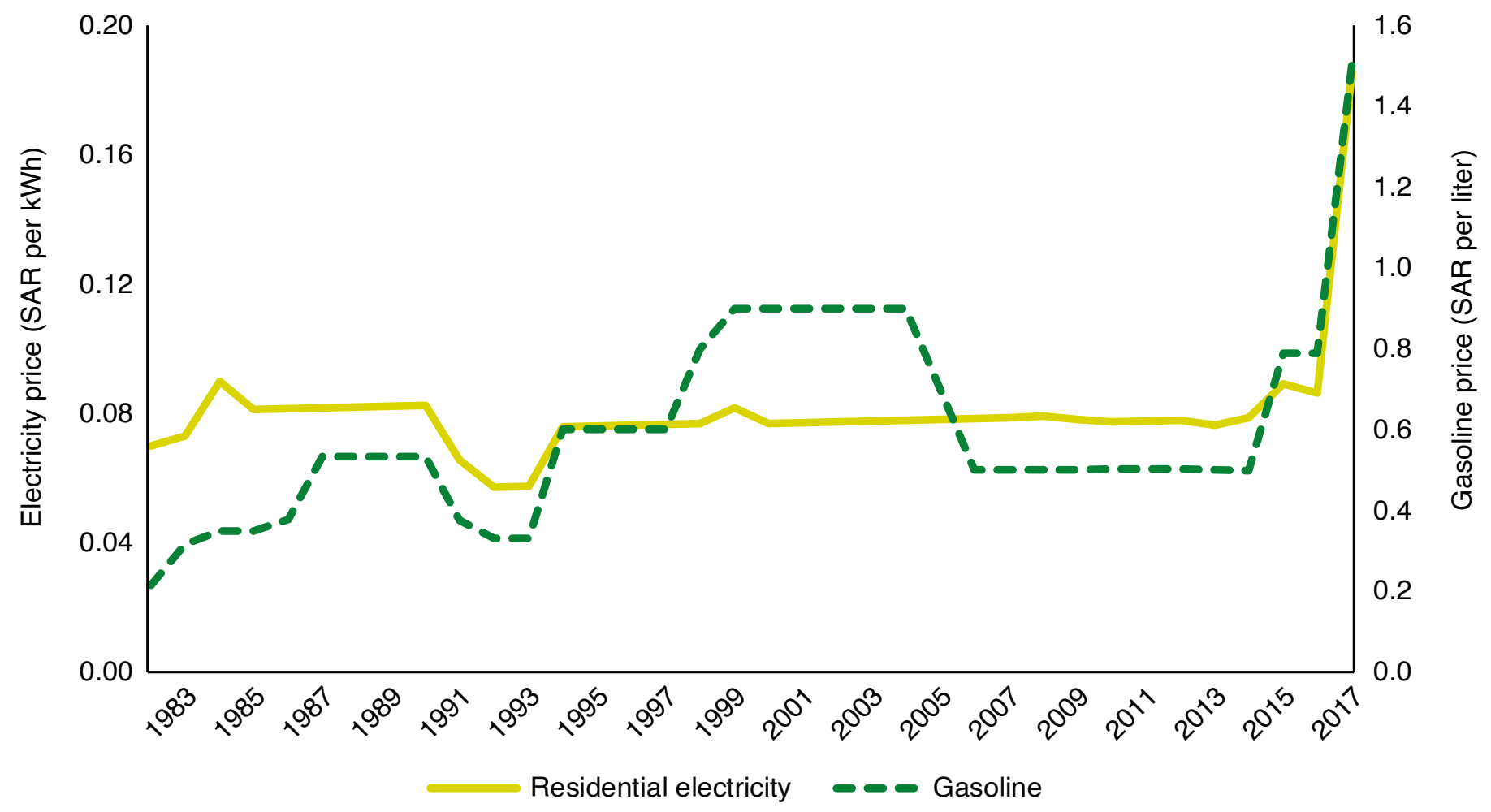

Sources: ECRA (2013b); ECRA (2019); Saudi Aramco (n.d.); KAPSARC analysis.

Figure 3. Real GDP and population in Saudi Arabia.

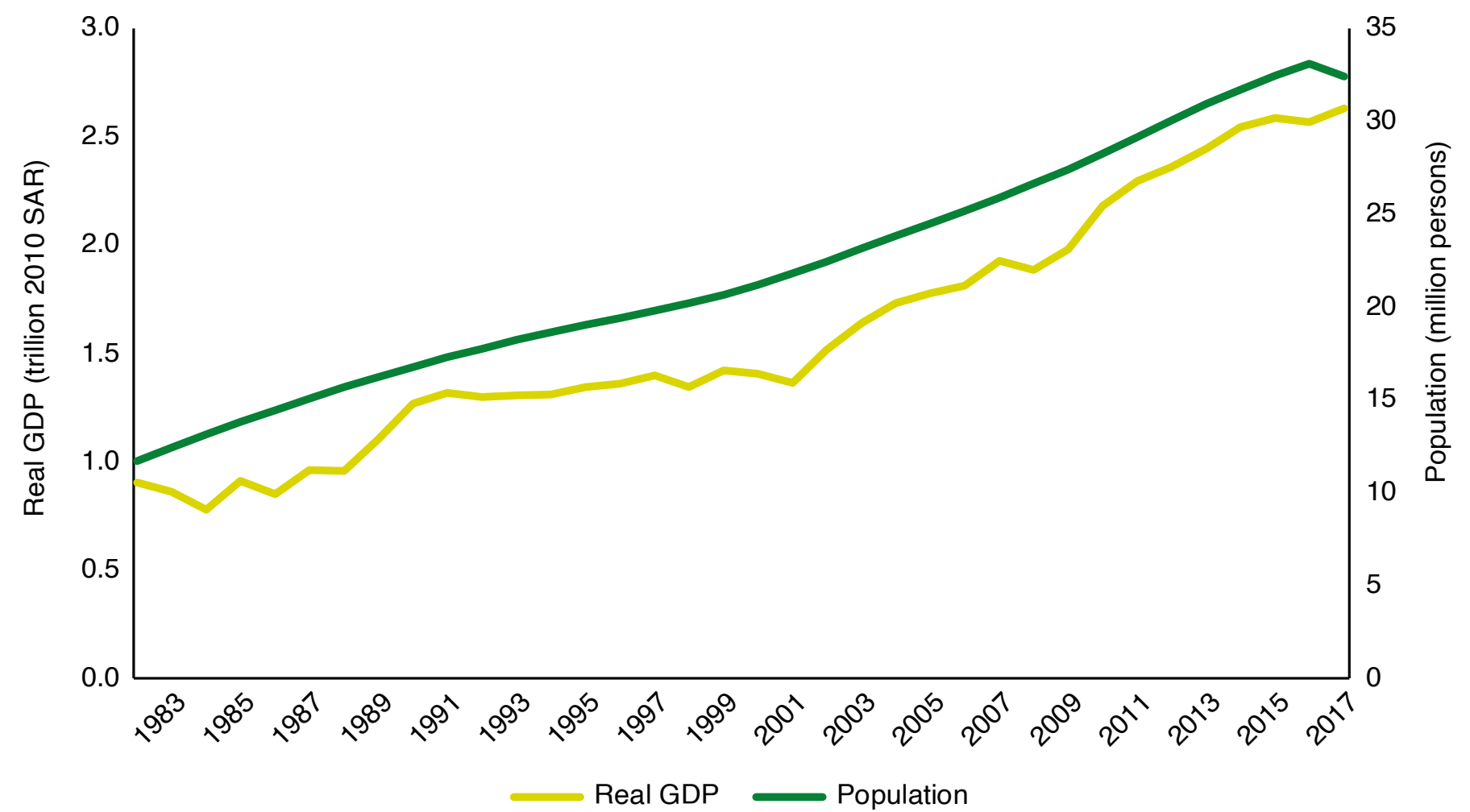

Sources: GaStat (2019); World Bank (2019); KAPSARC analysis. 
For the welfare analysis, we obtained international market prices for crude oil and gasoline from Bloomberg (2019). For crude oil we used the average Brent price in 2018 of US $\$ 71.7$ per barrel. For gasoline, we chose the free on board (FOB) spot price for regular gasoline at Rotterdam port, SAR 1.9 per liter. We acquired domestic energy prices in Saudi Arabia for fuels such as crude oil from Saudi Aramco (n.d.).

Finally, we applied US\$35 per tonne as an estimate of the external costs associated with electricity and gasoline consumption in Saudi Arabia, taken from Parry et al. (2014), whose methodology is described below. Calculating the costs of externalities can be difficult. The authors noted the existence of a wide range of estimates in the literature for external costs of $\mathrm{CO} 2$ emissions associated with a liter of gasoline or a kilowatthour (kWh) of electricity consumption for various countries. To find the external costs of air pollution in Saudi Arabia, they estimated the emissions inhaled by exposed populations and the resulting impact on mortality, and then converted the negative health impacts into monetary values. For accidents, Parry et al. considered the damage that drivers pose to pedestrians and cyclists as an external cost but injuries to occupants in single-vehicle collisions as internal, because drivers take such risks into account when deciding how much to drive. For multi-vehicle collisions, they treated $25 \%$ of the damages as external. For congestion, the authors considered the cost of time wasted as internal for drivers but external for passengers.

Figure 4. Annual cooling degree days in Saudi Arabia.

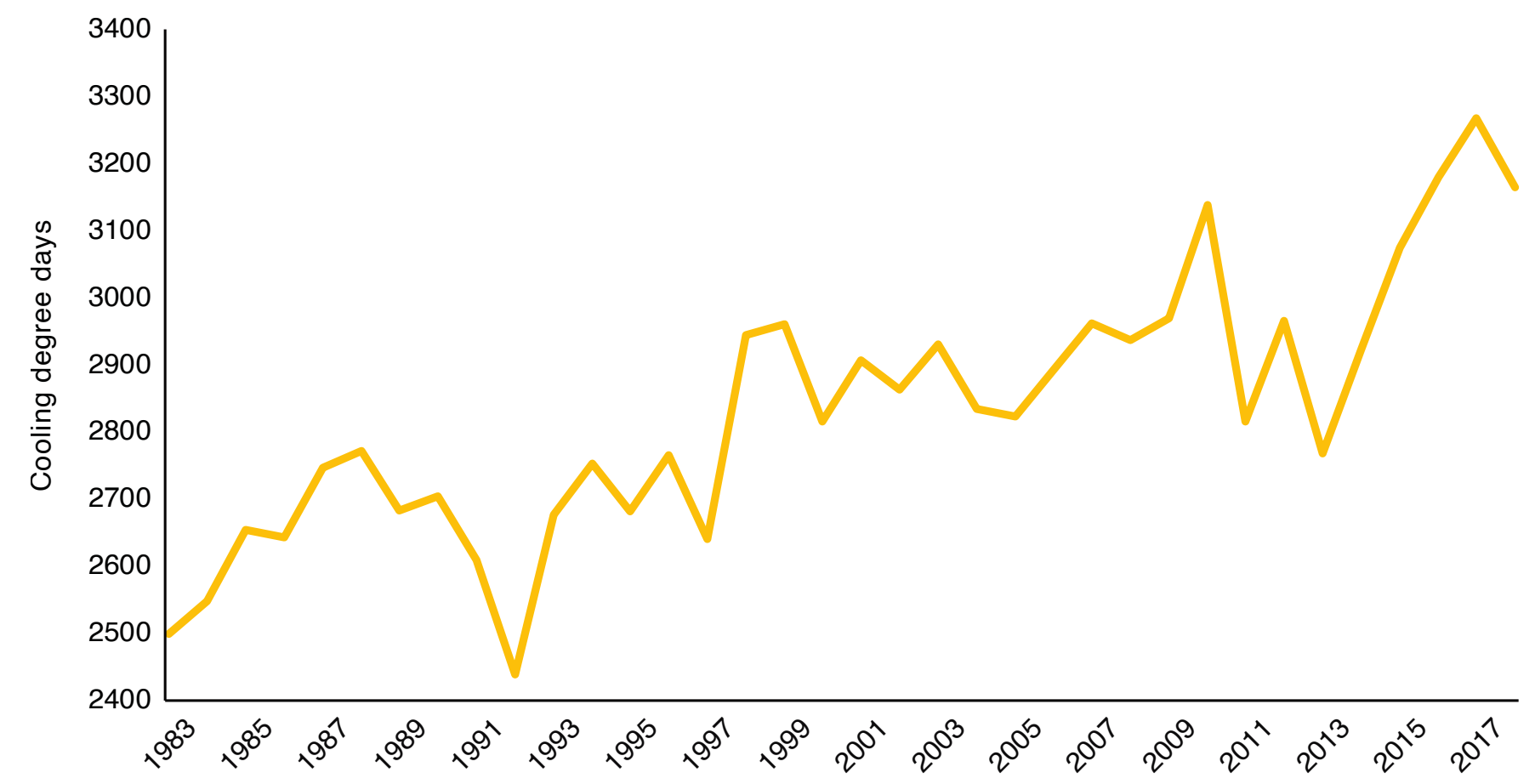

Sources: GaStat (2019); World Bank (2019); KAPSARC analysis. 


\section{Results and Discussion}

\section{Preferred econometric}

\section{models}

Using Harvey's (1990) structural time series model (STSM), we follow the general-to-specific methodology to obtain a preferred econometric model for each of our two sectors: gasoline and residential electricity. Both of these passed the full array of diagnostic checks.

\section{The gasoline demand model}

The preferred econometric model reveals that gasoline demand is both income and price inelastic (see Table 2). We find statistically insignificant short-run income elasticity and long-run income elasticity of 0.15 , reflecting that a $10 \%$ increase in income would raise gasoline consumption by $1.5 \%$. On the other hand, we estimate price elasticity of -0.09 and -0.13 in the short and long run, respectively. These results imply that a $10 \%$ rise in gasoline prices would reduce gasoline consumption by $0.9 \%$ in the short run (in that year) and $1.3 \%$ in the long run.

Table 2. Estimated elasticities from the preferred gasoline demand model.

Preferred model

\begin{tabular}{l|ll} 
Variable & Short-run coefficient & Long-run coefficient \\
\hline Income & Insignificant & 0.15 \\
\hline Price & -0.09 & -0.13 \\
\hline
\end{tabular}

Source: KAPSARC analysis. All estimated elasticities are statistically significant at the $1 \%$ level.

We obtain estimates of the UEDT in gasoline, which captures the effect of exogenous factors on gasoline demand over time. An upward (downward) UEDT would suggest that with income, population, and the gasoline price held constant between 1981 and 2018 (the study period), gasoline consumption would increase (decrease) due to exogenous factors. The most important exogenous factors to the model that can influence gasoline consumption are energy efficiency, urban sprawl, congestion, and the length of the road network. The UEDT therefore captures the combined effect of such exogenous factors on gasoline consumption over time.

Figure 5 reveals the upward sloping UEDT for gasoline consumption in Saudi Arabia from 1990 onwards. The exact causes of this trend are difficult to determine, but several exogenous factors appear to play a role. According to Sivak and Schoettle (2017), the average fuel economy of cars in the United States (U.S.) improved drastically between 1973 and 1991, reaching 21.2 miles per gallon (mpg). However, it rose by just 2.7 mpg between 1991 and 2015, a compound annual growth rate of only $0.5 \%$. Because Saudi Arabia only implemented fuel economy standards in the mid-2010s, the country likely achieved even fewer fuel economy improvements than the U.S. during the 1990s and 2000s. Furthermore, during this period the road network in the Kingdom grew extensively, while urban sprawl in major cities likely caused people to live further away from their jobs and families, increasing the need to drive and leading to an upward sloping UEDT. 
We had expected to observe a downward sloping UEDT for the most recent years, reflecting improvements in vehicle fuel economy since the government raised gasoline prices and implemented fuel economy standards in the mid-2010s. However, the UEDT continued to slope upward through 2018. According to Sheldon and Dua (2019), the average fuel economy of newly purchased cars in Saudi Arabia improved from $30.8 \mathrm{mpg}$ to $31.6 \mathrm{mpg}$ between 2013 and 2016, a 2.6\% improvement over four years. The average fuel economy improvement for the total stock of cars would be even smaller. This slight improvement was likely offset by other exogenous factors, such as increasing urban sprawl and higher congestion, which raise gasoline consumption.

Nevertheless, we expect the long-term impact of stricter fuel economy standards and higher gasoline prices on consumer preferences to cause the UEDT to slope downward in the coming years.

Figure 5. Estimated UEDT for gasoline consumption.

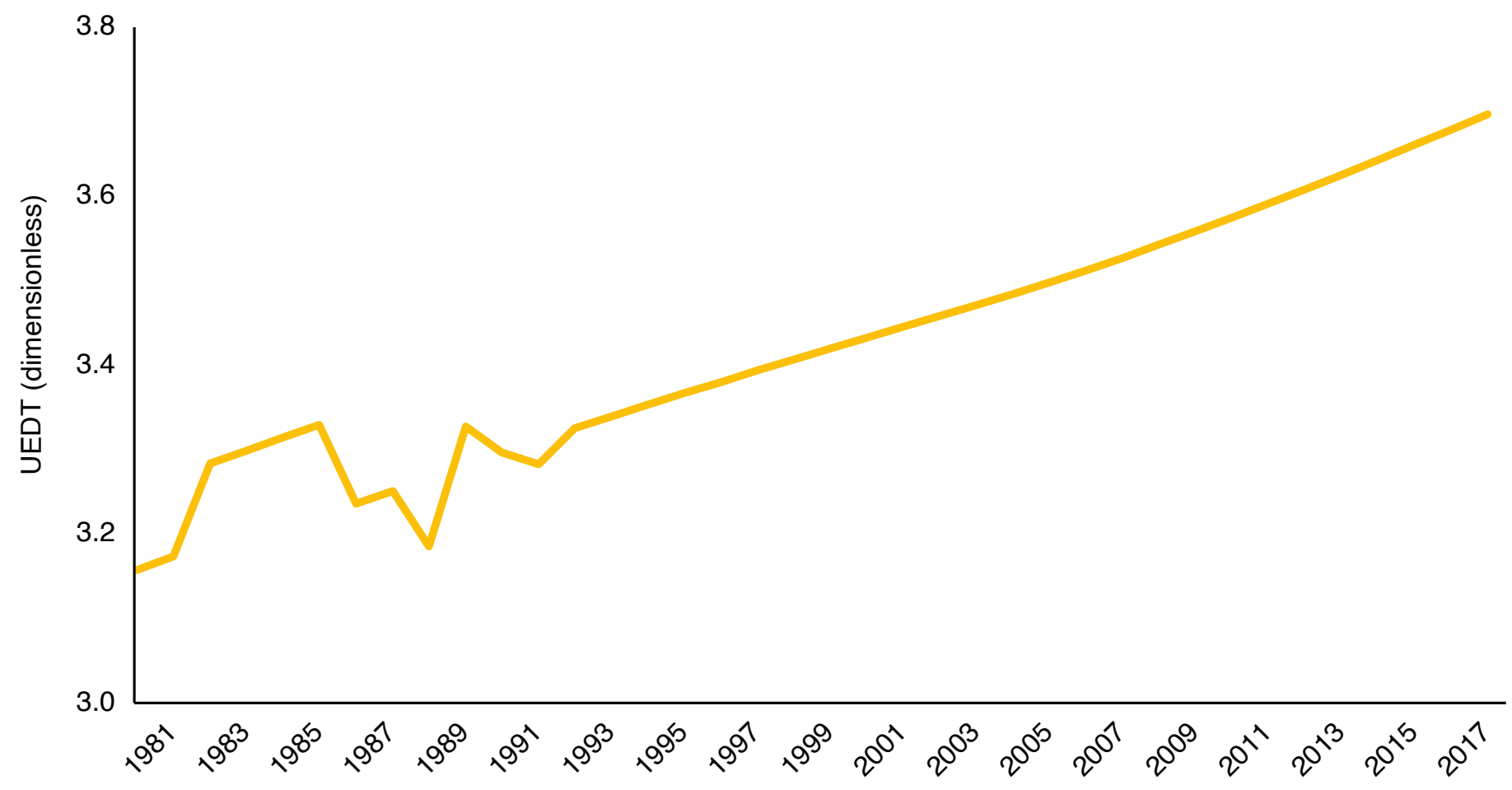

Source: KAPSARC analysis.

\section{The Residential Electricity Demand Model}

The preferred model indicates that residential electricity demand is income, price, and CDD inelastic (see Table 3). The income elasticity is statistically insignificant in the short run and 0.22 in the long run; price elasticity is -0.09 in both the short and long run; and CDD elasticity is 0.39 in both the short and long run.

As described above for gasoline, we employ the STSM approach to estimate the UEDT in residential electricity demand. The most 
important factors that are exogenous to our model are energy efficiency, appliance ownership, and average household size. The UEDT thus captures the combined effect of such exogenous factors on residential electricity consumption over time.

Figure 6 finds upward sloping UEDT for residential electricity consumption in Saudi Arabia through 2014, likely due to rising ownership rates of air conditioners and other appliances during the study period. Income only partially captures appliance ownership because, even when earnings are fixed, households can purchase more appliances as new technologies enter the market. Furthermore, the government implemented very few energy efficiency policies prior to the reforms of the 2010 s.
From 2014 onwards, the UEDT slopes downward, reflecting improvements in energy efficiency standards. It is unlikely that other exogenous factors such as household size or appliance ownership changed significantly in such a short period. The Saudi Energy Efficiency Center and the Saudi Standards, Metrology, and Quality Organization launched numerous programs in the 2010s, including mandatory thermal insulation for buildings, minimum energy efficiency ratios for air conditioners, energy efficiency awareness campaigns, and energy efficiency labeling for appliances. As the authorities expand energy efficiency policies, we expect a steeper downward slope for residential electricity UEDT in the future.

Table 3. Estimated elasticities from the preferred residential electricity demand model.

Preferred model

\begin{tabular}{l|ll} 
Variable & Short-run coefficient & Long-run coefficient \\
\hline Income & Insignificant & 0.22 \\
\hline Price & -0.09 & -0.09 \\
\hline CDD & 0.39 & 0.39 \\
\hline
\end{tabular}

Source: KAPSARC analysis. All estimated elasticities are statistically significant at the $1 \%$ level.

\section{The economic and welfare impacts of energy price reform}

Implicit subsidies characterize Saudi Arabia's domestic energy market: the government sets in-country prices for crude oil and refined products well below international levels. Although domestic sales may be profitable (i.e., above production costs), this forces producers to forgo higher revenues that could be earned by exporting to the international market. Thus international (export) market prices represent the true opportunity cost of domestic energy sales.

\section{Gasoline price reform}

We use the preferred gasoline demand model to generate a demand curve for 2018 in order to measure the welfare gains from gasoline price increases. This analysis holds all other variables (income, population, and UEDT) fixed at 2018 levels while decreasing the gasoline price from SAR 1.50 per liter, the actual weighted average price in 2018, to SAR 0.79 per liter; what it would have been at the start of the year without reforms. 
This allows us to estimate the welfare benefits generated by current prices versus a counterfactual scenario in which they continued at their 2016-2017 levels.

Figure 6. Estimated UEDT for residential electricity consumption.

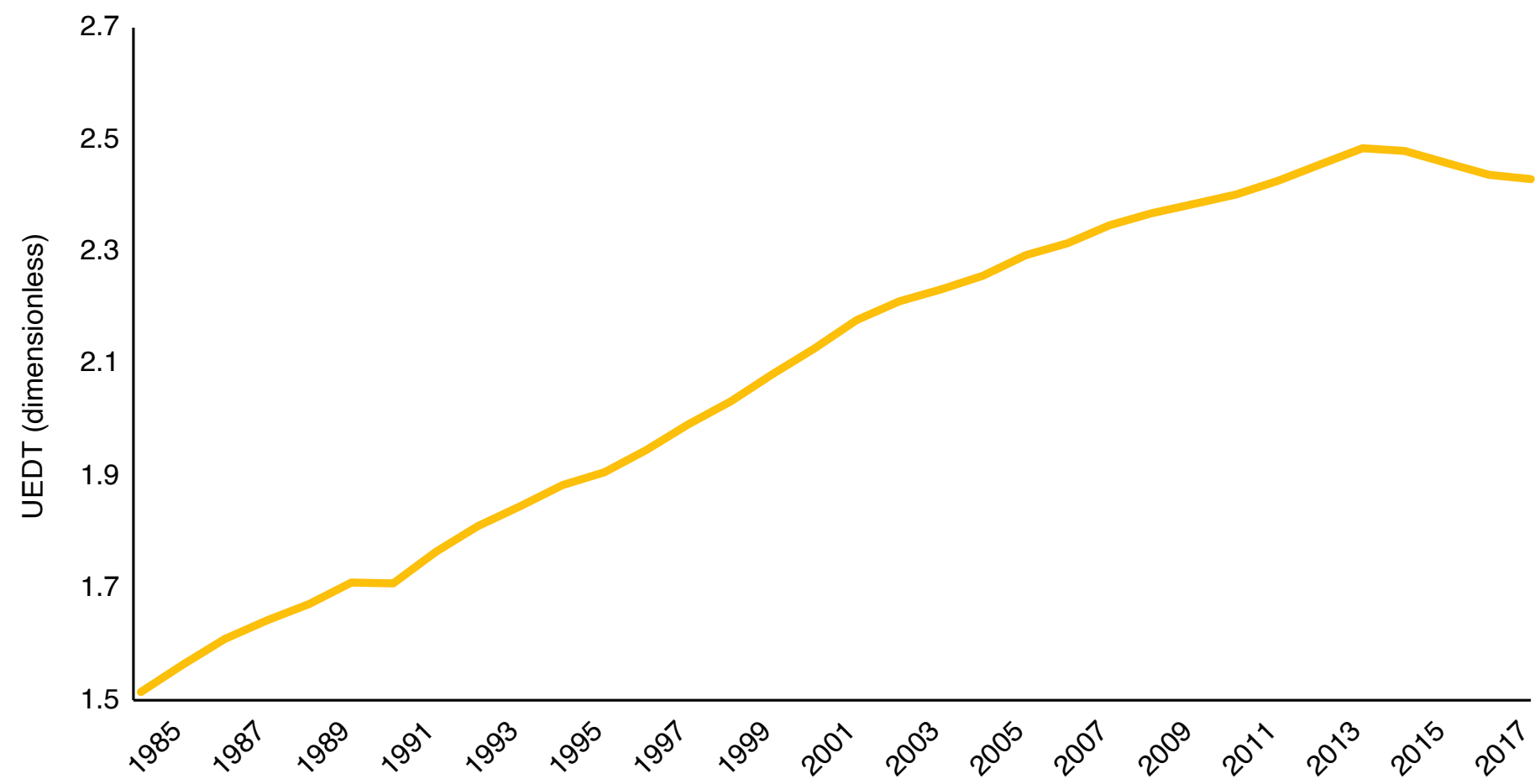

Source: KAPSARC analysis.

The welfare analysis reveals that the increase in gasoline prices reduced the consumer surplus by SAR 24.2 billion, while raising the producer surplus by SAR 21.9 billion (see Table 4). Lower domestic consumption frees up oil/gasoline for export at international market prices, lifting revenues for the oil and gas sector by an additional SAR 4.4 billion. Therefore, producers enjoy a total gain of SAR 26.3 billion, SAR 2.1 billion more than the loss suffered by consumers. This increase in total surplus equals the SAR 2.1 billion deadweight loss eliminated due to the reduction in the gasoline subsidy, as shown by Atalla, Gasim, and Hunt (2018).

Saudi Aramco, the national oil company, either wholly or partially owns all the refineries in the country, and the company's earnings comprise most of the government's revenues. The company controlled around $70 \%$ of total gasoline production at domestic refineries in 2017 (Saudi Aramco 2017). Based on this figure, the gasoline price reform of 2018 boosted government revenues by SAR 18.4 billion $-70 \%$ of the total increase in producer surplus. We note that this estimate may be low because Aramco has been actively increasing its market share since 2017. If the increase in producer surplus were fully passed on to the state, government revenues would have increased by the full SAR 26.3 billion.

In addition to the increase in total surplus, gasoline price reform brings substantial benefits to Saudi 
Arabia's economy by reducing negative externalities. The four major external costs associated with gasoline consumption are $\mathrm{CO} 2$ emissions, local air pollution, traffic congestion, and road accidents. Our analysis shows that the gasoline price reform of 2018 saved between 2.0 billion liters in the short run and 2.8 billion liters in the long run compared with the no-reform scenario. Using monetary estimates for per unit external costs (Parry et al. 2014), we estimated the gain from reduced external costs to be SAR 4.7 billion and SAR 6.6 billion in the short and long run, respectively. Summing the increase in total surplus and the reduction in external costs yields a total welfare gain of SAR 8.8 billion for the Saudi economy as a result of gasoline price reform in 2018.

The short-run results reflect the savings that would be obtained in the same year only, reflecting the short-run response of consumers. The long-run results reflect the savings that would be obtained annually if consumers were given time to respond fully to the price increase. In our gasoline demand model, the long-run response takes years. In the electricity model, the short-run and long-run responses are equal, in which case the 'single' response is generally referred to as a long-run response.

The total reduction in external costs highlighted above includes the monetary benefits from reduced $\mathrm{CO} 2$ emissions. Nevertheless, in the context of global climate change mitigation it is helpful to highlight exactly how many tonnes of CO2 emissions were avoided because of the gasoline price reform. Assuming that burning a liter of gasoline generates around 2.3 kilograms of CO2 emissions, the gasoline price reform would have reduced the country's carbon footprint by 4.6 million tonnes annually in the short run and 6.4 million tonnes annually in the long run.
It is important to note that these estimates represent only single-year gains and would continue to accumulate over time.

\section{Electricity price reform}

Following the same approach, we use the preferred residential electricity demand model to generate a demand curve for 2018, in order to measure the welfare gains from the residential electricity price increase. We hold all other variables (income, population, CDD, and the UEDT) fixed at 2018 levels, and allow the electricity price to decrease from SAR 0.185 to 0.086 per $\mathrm{kWh}$, reflecting the real weighted average electricity price in 2018 and what it would have been at the start of that year in the absence of reforms, respectively. This allows us to estimate the welfare benefits from the price reform versus a counterfactual no-reform scenario in which electricity prices remained at their 2016-2017 levels.

The welfare analysis finds that price reform reduces consumer surplus by SAR 13.3 billion but raises producer surplus by SAR 12.1 billion (see Table 4). The latter represents increased revenues for the power sector. Residential electricity consumption drops from 139 TWh under a no-reform scenario to actual consumption of $130 \mathrm{TWh}$. This 9 TWh reduction in electricity consumption saves 15.5 million barrels of crude oil. Assuming that the crude oil saved was exported at the average Brent price in 2018, this generates an additional revenue of SAR 4.6 billion for the oil and gas sector. The total gain for producers is therefore SAR 16.7 billion. Summing the loss to consumers and total gain for producers yields an increase in total surplus of SAR 3.4 billion.

The SAR 4.6 billion increase in revenues for Saudi Aramco represents increased revenues for the government. Furthermore, the Saudi government 
controls $81.2 \%$ of the Saudi Electric Company (SEC) through $74.3 \%$ direct ownership plus an additional $6.9 \%$ through shares held by Saudi Aramco. Therefore, the increase in government revenues from the power sector is SAR 9.8 billion. Overall, the total increase in government revenues because of electricity price reform is SAR 14.4 billion.

As with gasoline, in addition to helping to increase the total surplus, electricity price reform also reduces negative externalities. The two major external costs associated with electricity consumption are $\mathrm{CO} 2$ emissions and local air pollution. Using monetary estimates for per unit external costs (Parry et al. 2014), we estimate the gain from reduced external costs to be SAR 0.4 billion. Adding this to the increase in total surplus derived above yields a total welfare gain of SAR 3.8 billion for Saudi Arabia, as a result of the residential electricity price reform of 2018. In the long run, higher electricity prices will likely reduce the carbon intensity of the country's fuel mix, thereby changing the external costs of $\mathrm{CO} 2$ emissions per $\mathrm{kWh}$ of electricity. However, such higher-order, long-term effects are beyond the scope of this study.

It is helpful to show exactly how many tonnes of $\mathrm{CO} 2$ emissions were avoided due to price reform. Assuming each $\mathrm{kWh}$ of electricity savings avoids roughly 0.6 kilograms of $\mathrm{CO} 2$ emissions that would have been produced by using fossil fuels to generate electricity, then the electricity price reform of 2018 resulted in around 5.6 million tonnes of avoided $\mathrm{CO} 2$ emissions in that year.

As noted for gasoline above, these estimates represent only single-year gains in 2018 and should continue to accumulate over time.

Table 4. The changes for consumers, producers, the government, and social welfare caused by the energy price reforms.

Due to:

\begin{tabular}{lll} 
Changes in: & Gasoline price reform in 2018 & Residential electricity price reform in 2018 \\
\hline Consumer surplus & -24.2 & -13.3 \\
Producer surplus & 21.9 & 12.1 \\
Increase in export revenues & 4.4 & 4.6 \\
\hline Increase in government revenues & $18.4^{*}$ & $14.4^{\star *}$ \\
\hline Total market surplus & 2.1 & 3.4 \\
External cost reduction & 6.6 & 0.4 \\
\hline Total welfare change & 8.8 & 3.8 \\
\hline
\end{tabular}

Source: KAPSARC analysis.

Notes:

*Estimated assuming 70\% government ownership of gasoline producers.

${ }^{\star *}$ Estimated using $81.2 \%$ direct and indirect government ownership of the SEC. 


\section{Decomposing the demand response}

\section{Decomposing the gasoline demand response}

Figure 7 shows the decomposition results for gasoline consumption from 2008-2018. The black dots represent the year-on-year changes in gasoline consumption, while the stacked columns reveal the contributions of each factor or driver to that change.

For all periods, with one exception, the population effect was positive, meaning that the growing population in Saudi Arabia contributed to an increase in gasoline consumption. In 2017-2018, expatriate levies and other similar policies caused many non-Saudis to leave the country, decreasing gasoline consumption.

The income effect, measured through real GDP per capita, was positive in many periods, but sometimes negative. This may be because real GDP per capita grew slowly and fluctuated over the last several decades. A smoother income effect may have been obtained using real household disposable income, but time series data for it do not yet exist.

The UEDT effect was generally positive. As noted previously, this was likely due to an expanding road network, urban sprawl, and limited fuel economy improvements.

The lagged effect, which captures the impact of changes in income, population, prices, and the UEDT that occurred in past periods (not in the current period) was generally positive.
The residual effect was found to fluctuate, with equal positive and negative values observed. It can therefore be ignored, since it primarily captures statistical noise in the econometric models.

The price effect was particularly interesting. In most years, the gasoline price remained flat in nominal terms and the price effect was insignificant. The two periods that exhibit the largest impact are those in which gasoline price reforms were implemented. The first wave of gasoline price reform, in 2015-2016, reduced gasoline consumption by 1.3 billion liters, and the second wave, in 2017-18, by 1.9 billion liters. Therefore, gasoline price reform was the biggest contributor to the -2.2 billion liter change in gasoline consumption between 2017 and 2018.

\section{Decomposing the residential electricity demand response}

Figure 8 shows the decomposition results for residential electricity consumption from 2008-2018. The black dots represent the year-on-year change in residential electricity consumption, while the stacked columns reveal the contributions of each factor or driver to that change.

The population effect was a consistently positive driver of residential electricity consumption growth. The only exception was 2017-2018, in which expat levies and other similar policies caused many non-Saudis to leave the country, decreasing electricity consumption.

The income effect, measured through real GDP per capita, varied across periods. This is likely because real GDP per capita grew slowly and fluctuated. 
The UEDT effect was positive through 2013. This was likely due to increasing appliance ownership and limited energy efficiency improvements for most of the study period. From 2014 onward, the UEDT effect became negative, likely due to the Kingdom's energy efficiency programs, such as mandatory thermal insulation for buildings, stringent minimum energy efficiency standards, energy efficiency labelling, and energy efficiency awareness campaigns. Summing the four negative UEDT effects shows that these energy efficiency measures helped save at least 7.7 TWh of electricity consumption in the residential sector from 2014 to 2018 .

As with gasoline, the residual effect fluctuates with approximately equal positive and negative values observed, and can thus be ignored.
The weather effect contributed positively and negatively. Unsurprisingly, it was positive in the last five periods (2013 to 2018) as the average annual temperature in Saudi Arabia increased (World Bank 2019), driving up electricity consumption, except in 2017-2018, as temperatures in 2018 were slightly cooler (World Bank 2019).

The price effect was once again particularly interesting. During most periods, residential electricity prices did not change significantly. Therefore, the price effect had no significant impact, including in 2015-2016 when the first wave of reforms was implemented. However, in 2017-2018, the more substantial second wave of electricity price reforms had a major impact. Electricity prices in the first and second segments of consumption increased by $260 \%$ and $80 \%$, respectively. The decomposition analysis found a price effect of -9.1 TWh for the 2017-2018 period, indicating that residential electricity price reform was the biggest contributor to the -13.0 TWh change in electricity consumption between 2017 and 2018. 
Figure 7. Change in gasoline consumption decomposed into six contributing factors called effects.

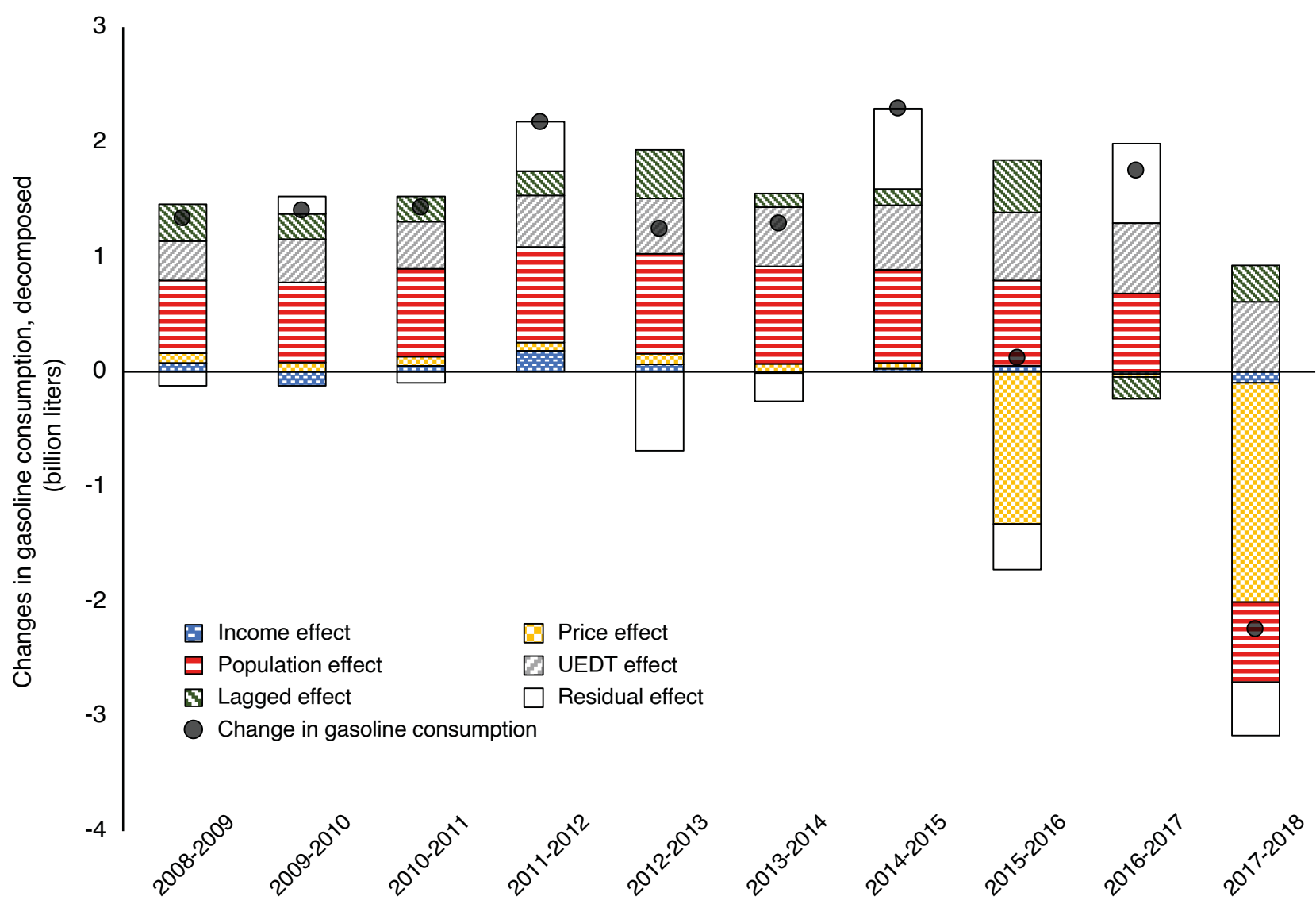

Figure 8. Change in residential electricity consumption decomposed into six contributing factors called effects.

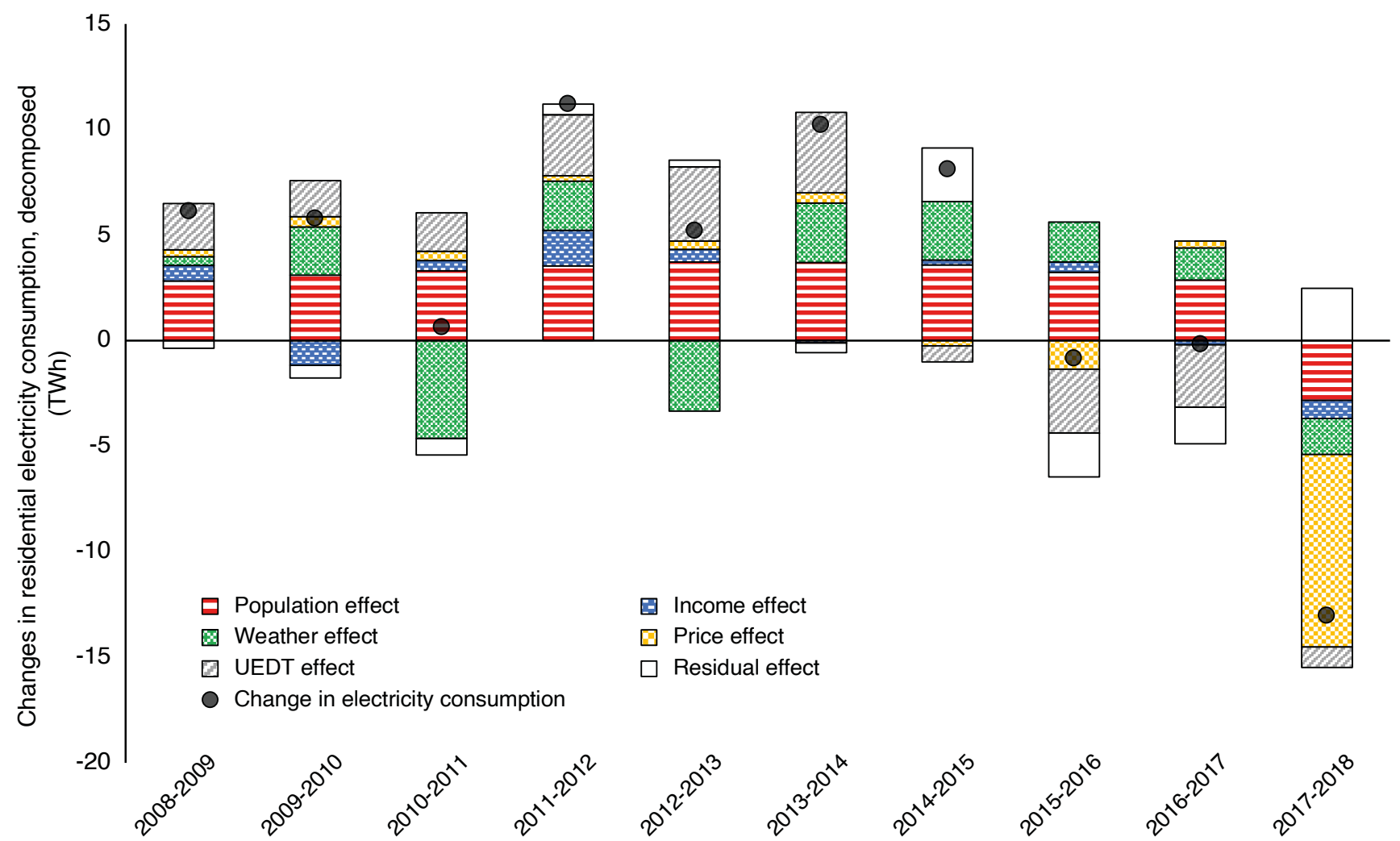




\section{Conclusion}

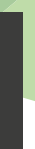
$\mathrm{n}$ this paper we model gasoline and residential electricity demand in Saudi Arabia for an estimation period that includes recently implemented energy price reforms. We formulate econometric models to measure the economic and environmental impacts of the Kingdom's 2018 energy price reform.

Our gasoline demand model reveals that gasoline demand in Saudi Arabia is strongly price and income inelastic, with estimated long-run elasticities of -0.13 and 0.15 , respectively. Studies such as Algunaibet and Matar (2018) have suggested that, as gasoline prices undergo very large increases, consumers may become more price responsive and gasoline more price elastic. However, we find no evidence of this, likely due to the absence of alternative transport options in major cities in Saudi Arabia.

Our electricity demand model reveals that residential electricity demand is also strongly price and income inelastic, with estimated long-run elasticities of -0.09 and 0.22 , respectively. This price inelasticity is likely due to the need for cooling in Saudi Arabia in the summer months, and the lack of alternative available means for consumers to cool their homes.

We also conduct a welfare analysis to calculate the economic impact of energy price reform on consumers, producers, the government, and, ultimately, on overall social welfare in the Kingdom. Our calculations indicate that energy price reforms in gasoline and residential electricity delivered increases in 2018's total market surplus of SAR 2.1 billion and 3.4 billion, respectively. Higher gasoline and residential electricity prices also reduced negative externalities such as $\mathrm{CO} 2$ emissions and air pollution, benefits worth SAR 6.6 billion and SAR 0.4 billion, respectively. The former is considerably larger due to reductions in road congestion and traffic accidents. Combining the total market surplus gains and the reductions in external costs, our analysis reveals that in 2018 the energy price reforms of gasoline and residential electricity delivered total welfare gains of SAR 8.8 billion and SAR 3.8 billion, respectively. We note that these estimates reflect single-year improvements only, and that Saudi Arabia's economy will continue to benefit from the price reforms for years to come.

In Saudi Arabia, the government fully or partially owns most energy companies. By applying the direct and indirect shares of government ownership of energy companies such as the SEC and refineries, we can obtain a more accurate estimate of the government revenue uplift. Accounting for the shares in government ownership, we find that the energy price reforms in gasoline and residential electricity likely increased government revenue in 2018 by SAR 18.4 billion and SAR 14.4 billion, respectively (SAR 32.8 billion in total).

Finally, this study uses decomposition analysis to isolate the impact of energy price reform on energy consumption. This highlights that the 2018 reforms were the most important contributors to the large year-on-year decreases in energy consumption observed that year. For gasoline, price reform accounts for 1.9 billion liters of the 2.2 billion liter annual decrease, while for residential electricity, higher prices contributed 9.1 TWh of the 13.0 TWh annual decline. In both cases, no other factor played as important a role as energy price reform. Although our regression analysis shows that gasoline and residential electricity demand is price inelastic, the very large percentage increases in prices in 2018 following the second fuel price reform resulted in these considerable declines in energy consumption.

In conclusion, our analysis reveals the positive economic and environmental impact of energy price 
reform in Saudi Arabia, a country that had some of the lowest energy prices - and highest implicit subsidies - globally. This highlights to policymakers in other economies the potential benefits of higher energy prices. With a mechanism in place to minimize the negative impact on lower-income households, higher energy prices can be an effective tool for both maximizing economic efficiency and mitigating climate change, while protecting the basic energy consumption needs of economically vulnerable demographic segments.
Future work in this area will likely explore how energy-related elasticities differ by income brackets. Another important area of research could be to disentangle the effects of energy price reform and the Citizens' Account Program on households of different income brackets. As more disaggregated data becomes available, it will be possible to run microeconometric regression analyses to better understand energy demand and energy price reform at the household level. 


\section{References}

Alarenan, Shahad, Anwar Gasim, and Lester C. Hunt. 2019. "Modeling Industrial Energy Demand in Saudi Arabia." KAPSARC Discussion Paper.

Algunaibet, Ibrahim M., and Walid Matar. 2018. "The Responsiveness of Fuel Demand to Gasoline Price Change in Passenger Transport: A Case Study of Saudi Arabia." Energy Efficiency 11 (6): 1341-1358.

Ang, Beng W. 2005. "The LMDI Approach to Decomposition Analysis: A Practical Guide." Energy Policy 33, no. 7 (May): 867-871.

- - - 2015. "LMDI Decomposition Approach: A Guide for Implementation." Energy Policy 86 (November): 233-238.

Ang, Beng W., and Fuqiang Q. Zhang. 2000. "A Survey of Index Decomposition Analysis in Energy and Environmental Studies." Energy 25, no. 12 (December): 1149-1176.

Ang, Beng W., Fuqiang Q. Zhang, and Ki-Hong Choi. 1998. "Factorizing Changes in Energy and Environmental Indicators Through Decomposition." Energy 23, no. 6 (June): 489-495.

Argaam. 2019. "Labor Market Sees 1.6 mln Expats Leaving Due to Saudization Measures: Jadwa." Argaam. Accessed Feb 7, 2020. https://www.argaam.com/en/ article/articledetail/id/604654

Atalla, Tarek N., Anwar A. Gasim, and Lester C. Hunt. 2018. "Gasoline Demand, Pricing Policy, and Social Welfare in Saudi Arabia." Energy Policy 114 (March): 123-133.

Blazquez, Jorge, Lester C. Hunt, and Baltasar Manzano. 2017. "Oil Subsidies and Renewable Energy in Saudi Arabia: A General Equilibrium Approach." The Energy Journal 38:1-16.

Electricity and Cogeneration Regulatory Authority (ECRA). 2008. "ECRA Statistical Booklet 2008." Accessed Feb 7, 2020. https://www.ecra.gov.sa/ en-us/MediaCenter/doclib2/Pages/SubCategoryList. aspx?categoryID=5

- - . 2009. "ECRA Statistical Booklet 2009." Accessed Feb 7, 2020. https://www.ecra.gov.sa/en-us/MediaCenter/ doclib2/Pages/SubCategoryList.aspx?categoryID=5
- - - 2010. "ECRA Statistical Booklet 2010." Accessed Feb 7, 2020. https://www.ecra.gov.sa/en-us/MediaCenter/ doclib2/Pages/SubCategoryList.aspx?categorylD=5

- - - 2011. "ECRA Statistical Booklet 2011." Accessed

Feb 7, 2020. https://www.ecra.gov.sa/en-us/MediaCenter/ doclib2/Pages/SubCategoryList.aspx?categoryID=5

- - - 2012. "ECRA Statistical Booklet 2012." Accessed Feb 7, 2020. https://www.ecra.gov.sa/en-us/MediaCenter/ doclib2/Pages/SubCategoryList.aspx?categoryID=5

- - . 2013. "ECRA Statistical Booklet 2013." Accessed Feb 7, 2020. https://www.ecra.gov.sa/en-us/MediaCenter/ doclib2/Pages/SubCategoryList.aspx?categoryID=5

- - . 2013b. "ECRA Annual Report 2013." Accessed Feb 7, 2020. https://www.ecra.gov.sa/en-us/MediaCenter/ DocLib2/Pages/SubCategoryList.aspx?categoryID=4

- - - 2014. "ECRA Statistical Booklet 2014." Accessed Feb 7, 2020. https://www.ecra.gov.sa/en-us/MediaCenter/ doclib2/Pages/SubCategoryList.aspx?categorylD=5

- - - 2015. "ECRA Statistical Booklet 2015." Accessed Feb 7, 2020. https://www.ecra.gov.sa/en-us/MediaCenter/ doclib2/Pages/SubCategoryList.aspx?categorylD=5

- - - 2016. "ECRA Statistical Booklet 2016." Accessed Feb 7, 2020. https://www.ecra.gov.sa/en-us/MediaCenter/ doclib2/Pages/SubCategoryList.aspx?categorylD=5

- - - 2017. "ECRA Statistical Booklet 2017." Accessed Feb 7, 2020. https://www.ecra.gov.sa/en-us/MediaCenter/ doclib2/Pages/SubCategoryList.aspx?categorylD=5

- - - 2019. "ECRA Electricity Tariffs." Accessed Feb 7, 2020. https://www.ecra.gov.sa/en-us/ECRARegulations/ ElectricityTariff/Pages/Tariffconsumption.aspx

Ekins, Paul, and Terry Barker. 2001. "Carbon Taxes and Carbon Emissions Trading." Journal of Economic Surveys 15, no. 3 (July): 325-352.

Fiscal Balance Program (FBP). 2017. "Fiscal Balance Program: Balanced Budget 2020.” A program by SV2030.

- - . 2018. "Fiscal Balance Program: 2018 Update." A program by SV2030. 
- - - 2019. "Fiscal Balance Program: 2019 Update." A program by SV2030.

General Authority for Statistics (GaStat). 2019. Statistics Library. Accessed Feb 7, 2020. https://www.stats.gov.sa/ en

Harvey, Andrew C. 1990. Forecasting, Structural Time Series Models and the Kalman Filter. Cambridge (UK): Cambridge University Press.

International Monetary Fund (IMF). 2018. "Saudi Arabia: Article IV Consultation." Press release and staff report.

Jodi Oil. 2019. JODI Oil World Database. Accessed Feb 7, 2020. https://www.jodidata.org/oil/

Lahn, Glada, and Paul Stevens. 2011. "Burning Oil to Keep Cool." Chatham House.

Ministry of Energy, Industry and Mineral Resources (MEIM). 2019. Petroleum Statistics. Accessed Feb 7, 2020. https://www.meim.gov.sa/arabic/Energy/Pages/ petroleum-statistics.aspx

Parry, Ian W. H., Dirk Heine, Eliza Lis, and Shanjun Li. 2014. Getting Energy Prices Right: From Principle to Practice. International Monetary Fund.
Saudi Arabian Monetary Authority (SAMA). 2019. "SAMA Annual Statistics." Accessed Feb 7, 2020. http://www. sama.gov.sa/en-U.S./EconomicReports/Pages/YearlyStatistics.aspx

Saudi Aramco. 2017. "Facts and Figures 2017." Accessed February 12, 2020. https://www.saudiaramco.com/-/ media/publications/corporate-reports/2017-facts-and-figures-en.pdf

- - - n.d. Private communication. Dharhan, Saudi Arabia.

Saudi Vision 2030 (SV2030). 2016. Accessed Feb 7, 2020. https://vision2030.gov.sa/download/file/fid/417

Sivak, Michael, and Brandon Schoettle. 2015. "On-Road Fuel Economy of Vehicles in the United States: 1923-2015." Sustainable Worldwide Transportation UMTRI-2015-25.

World Bank. 2018. "Climate Change Knowledge Portal - Climate Data." Accessed Feb 7, 2020. https://climateknowledgeportal.worldbank.org/country/saudi-arabia/ climate-data-historical

- - - 2019. "World Bank Open Data." Accessed Feb 7, 2020. https://data.worldbank.org 
W e encountered an issue related to the population data for 2018. News sources (such as Argaam [2019]) widely report that the expatriate levies imposed by the Fiscal Balance Program, along with similar reforms, caused up to 1.6 million foreign workers to leave Saudi Arabia between 2017 and 2018. However, this trend was not reflected in the 2018 population estimates obtained from either the World Bank (2019) or the General Authority for Statistics (GaStat) (2019).

Table A1 displays population figures for 2017 and 2018. The World Bank reports an increase from 33.1 million in 2017 to 33.7 million in 2018, and GaStat from 32.6 million to 33.4 million. Furthermore, the GaStat numbers show growth for both Saudi and non-Saudi segments, which account for around two-thirds and one-third of the population, respectively. However, GaStat notes that the estimates are preliminary, based on the 2016 census, and subject to change.

By contrast, GaStat's Labor Force Survey (2019) shows a clear fall in the number of employed non-Saudis between 2017 and 2018, from 10.8 to 9.9 million. Because some of these workers have non-employed family members in the country, this implies an even bigger decline in the total number of non-Saudis. The Labor Force Survey uses statistics from sources including the Ministry of Labor and Social Development and the General Organization for Social Insurance, which directly collect data on employed non-Saudis.

Given that GaStat's population estimates are preliminary (and likely estimated in 2016 or 2017, before any of the reforms occurred), and that the World Bank likely bases its numbers on these estimates, we adjust the 2018 population figures using GaStat's Labor Force Survey. We assume that GaStat's population estimate for Saudi nationals in 2018 is correct, since the expatriate levies do not impact them, and adjust only the non-Saudi population estimate by applying the percentage decrease in employed non-Saudis between 2017 and $2018(-8.3 \%)$ to derive the total non-Saudi population (see Table A1).

The resulting adjustment to the total population indicates a $2.1 \%$ year-on-year decrease in 2018, from 32.6 million to 32.1 million. Applying this growth rate to the World Bank figures shows a corresponding decline from 33.1 million to 32.4 million.

For all analyses conducted in this paper, we use the adjusted 2018 population figures. 
Table A1. Population figures for Saudi Arabia.

\begin{tabular}{|c|c|c|c|c|c|}
\hline \multirow[b]{2}{*}{ Year } & \multirow{2}{*}{$\begin{array}{c}\text { GaStat's (2019) Labor } \\
\text { Force Survey* } \\
\text { Employed non-Saudis }\end{array}$} & \multicolumn{3}{|c|}{ GaStat's (2019) population estimates ${ }^{\star *}$} & \multirow{2}{*}{$\begin{array}{c}\begin{array}{c}\text { World Bank data } \\
(\mathbf{2 0 1 9})\end{array} \\
\text { Total population }\end{array}$} \\
\hline & & Saudis & Non-Saudis & Total population & \\
\hline 2017 & $10,788,709$ & $20,427,357$ & $12,185,284$ & $32,612,641$ & $33,099,147$ \\
\hline 2018 & $9,892,723$ & $20,768,627$ & $12,645,033$ & $33,413,660$ & $33,699,947$ \\
\hline $\begin{array}{c}\text { 2017-2018 growth } \\
\text { rate } \\
\end{array}$ & $-8.3 \%$ & $1.7 \%$ & $3.8 \%$ & $2.5 \%$ & $1.8 \%$ \\
\hline Year & $\begin{array}{l}\text { Employed non-Saudis } \\
\text { (unadjusted) }\end{array}$ & $\begin{array}{c}\text { Saudis } \\
\text { (unadjusted) }\end{array}$ & $\begin{array}{c}\text { Non-Saudis } \\
\text { (2018 adjusted) }\end{array}$ & $\begin{array}{l}\text { Total population } \\
\text { (2018 adjusted) }\end{array}$ & $\begin{array}{l}\text { Total population } \\
\text { (2018 adjusted) }\end{array}$ \\
\hline 2017 & $10,788,709$ & $20,427,357$ & $12,185,284$ & $32,612,641$ & $33,099,147$ \\
\hline 2018 & $9,892,723$ & $20,768,627$ & $11,173,315$ & $32,057,925$ & $32,418,442$ \\
\hline $\begin{array}{l}2017-2018 \text { adjusted } \\
\text { growth rate }\end{array}$ & $-8.3 \%$ & $1.7 \%$ & $-8.3 \%$ & $-2.1 \%$ & $-2.1 \%$ \\
\hline
\end{tabular}

Sources: World Bank (2019); GaStat (2019).

Notes:

* The figures for employed non-Saudis for 2017 and 2018 were measured at the end of the second quarter of each year.

${ }^{* \star A}$ According to GaStat (2019), the total population estimates are only preliminary forecasts based on the 2016 census and not final. 
Notes

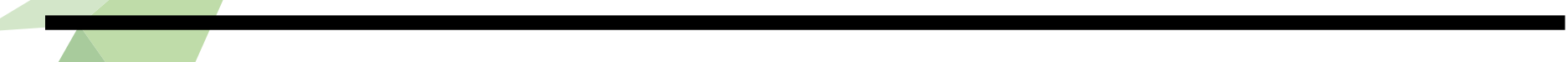




\section{About the Authors}

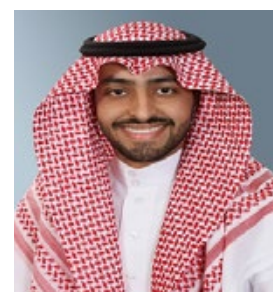

\section{Mohammad AI Dubyan}

Mohammad is a researcher in KAPSARC's Climate and Environment program. His research focuses on energy demand and energy efficiency. $\mathrm{He}$ is currently part of a project modeling energy demand in Saudi Arabia and estimating the economic impacts of energy price reform. He is also modeling Saudi Arabia's residential building stock to assess energy efficiency retrofit options. Mohammad holds an M.Sc. in Renewable and Clean Energy from the University of Dayton, United States.

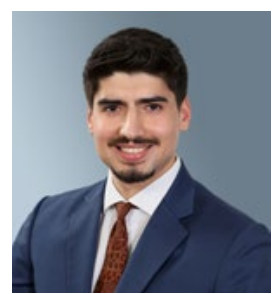

\section{Anwar Gasim}

Anwar is a Research Fellow in the Climate and Environment program at KAPSARC. His research focuses on energy demand, energy prices, and energy efficiency. He leads a project modeling energy demand in Saudi Arabia and estimating the economic impacts of energy price reform. $\mathrm{He}$ has published journal articles in leading energy economics journals. Anwar holds an M.Sc. in Electrical Engineering from KAUST, Saudi Arabia.

\section{About the Project}

This paper is part of the project titled 'Modeling Final Energy Demand Using the Structural Time Series Model.' This project examines how factors such as economic growth, income, energy prices, economic structure, and energy efficiency influence the demand for energy at national, sectoral, and household levels. This project also measures the impact of policies such as energy price reform on energy demand, the economy, and social welfare in the Kingdom. 
INAPSARC

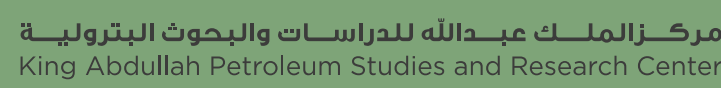

www.kapsarc.org 